University of Montana

ScholarWorks at University of Montana

$7-2004$

\title{
Effects of Natal Departure and Water Level on Survival of Juvenile Snail Kites (Rostrhamus sociabilis) in Florida
}

Victoria J. Dreitz

University of Montana - Missoula, victoria.dreitz@cfc.umt.edu

Wiley M. Kitchens

University of Florida

Donald L. DeAngelis

University of Miami

Follow this and additional works at: https://scholarworks.umt.edu/wildbio_pubs

Part of the Life Sciences Commons

Let us know how access to this document benefits you.

\section{Recommended Citation}

Dreitz, Victoria J.; Kitchens, Wiley M.; and DeAngelis, Donald L., "Effects of Natal Departure and Water Level on Survival of Juvenile Snail Kites (Rostrhamus sociabilis) in Florida" (2004). Wildlife Biology Faculty Publications. 53.

https://scholarworks.umt.edu/wildbio_pubs/53

This Article is brought to you for free and open access by the Wildlife Biology at ScholarWorks at University of Montana. It has been accepted for inclusion in Wildlife Biology Faculty Publications by an authorized administrator of ScholarWorks at University of Montana. For more information, please contact scholarworks@mso.umt.edu. 


\title{
EFFECTS OF NATAL DEPARTURE AND WATER LEVEL ON SURVIVAL OF JUVENILE SNAIL KITES (ROSTRHAMUS SOCIABILIS) IN FLORIDA
}

\author{
Victoria J. Dreitz, ${ }^{1,2,5}$ Wiley M. Kitchens, ${ }^{3}$ and Donald L. DeAngelis ${ }^{4}$ \\ ${ }^{1}$ Department of Biology, University of Miami, P.O. Box 249118, Coral Gables, Florida 33124, USA; \\ ${ }^{2}$ Florida Cooperative Fish and Wildlife Research Unit, P.O. Box 110450, University of Florida, Gainesville, \\ Florida 32611, USA; \\ ${ }^{3}$ U.S. Geological Survey, Florida Cooperative Fish and Wildlife Research Unit, University of Florida, Gainesville, \\ Florida 32611, USA; and \\ ${ }^{4}$ U.S. Geological Survey, Florida Integrated Science Centers, Department of Biology, University of Miami, \\ P.O. Box 249118, Coral Gables, Florida 33124, USA
}

\begin{abstract}
Aвstract.-Survival rate from fledging to breeding, or juvenile survival, is an important source of variation in lifetime reproductive success in birds. Therefore, determining the relationship between juvenile survival and environmental factors is essential to understanding fitness consequences of reproduction in many populations. With increases in density of individuals and depletion of food resources, quality of most habitats deteriorates during the breeding season. Individuals respond by dispersing in search of food resources. Therefore, to understand the influence of environmental factors on juvenile survival, it is also necessary to know how natal dispersal influences survival of juveniles. We examined effects of various environmental factors and natal dispersal behavior on juvenile survival of endangered Snail Kites (Rostrhamus sociabilis) in central and southern Florida, using a generalized estimating equations (GEEs) approach and model selection criteria. Our results suggested yearly effects and an influence of age and monthly minimum hydrologic levels on juvenile Snail Kite survival. Yearly variation in juvenile survival has been reported by other studies, and other reproductive components of Snail Kites also exhibit such variation. Age differences in juvenile survival have also been seen in other species during the juvenile period. Our results demonstrate a positive relationship between water levels and juvenile survival. We suggest that this is not a direct linear relationship, such that higher water means higher juvenile survival. The juvenile period is concurrent with onset of the wet season in the ecosystem we studied, and rainfall increases as juveniles age. For management purposes, we believe that inferences suggesting increasing water levels during the fledging period will increase juvenile survival may have short-term benefits but lead to long-term declines in prey abundance and possibly wetland vegetation structure. Received 13 February 2003, accepted 29 March 2004.
\end{abstract}

Resumen. - La tasa de supervivencia desde volantón a individuo reproductivo, o tasa de supervivencia juvenil, es una fuente de variación importante del éxito reproductivo a lo largo de la vida de un ave. Por esto, entender la relación entre la supervivencia juvenil y los factores ambientales es esencial para entender las consecuencias sobre la adecuación biológica de la reproducción en las poblaciones. Con el aumento de la densidad de individuos y la consecuente reducción de los recursos alimenticios, la calidad de la mayoría de los hábitats se deteriora durante la época reproductiva. Los individuos responden dispersándose fuera del área en busca de recursos alimenticios. Por lo tanto, para entender la influencia de los factores ambientales sobre la supervivencia de los juveniles, es necesario también entender cómo la dispersión natal afecta la supervivencia de los juveniles. Examinamos los efectos de varios factores ambientales y de la dispersión natal sobre la supervivencia de juveniles en la especie en peligro Rostrhamus sociabilis en el centro y norte de Florida. Utilizamos ecuaciones de estimación generalizadas (GEE) y criterios de selección de modelos. Nuestros resultados sugirieron efectos de año y una influencia de la edad y de los niveles mensuales hidrológicos sobre la sobrevivencia de juveniles. Otros estudios también han reportado variación anual en la supervivencia de los juveniles, y otros componentes de la reproducción también exhiben dicha variación. En otras especies también se han observado diferencias en la sobrevivencia juvenil asociadas con la edad. Nuestros resultados demuestran una asociación positiva entre los niveles de agua y la supervivencia de los juveniles. Sugerimos que ésta no es una relación lineal directa, de manera que niveles de agua mayores

5Present address: Colorado Division of Wildlife, 317 Prospect Road, Fort Collins, Colorado 80526, USA. E-mail: victoria.dreitz@state.co.us 
continúan implicando una mayor supervivencia juvenil. En el ecosistema que estudiamos, el período de juveniles coincide con el inicio de la época de lluvias y las precipitaciones aumentan a medida que los juveniles envejecen. Para propósitos de manejo, creemos que la inferencia que sugiere que el aumento de los niveles del agua durante el período de emplumamiento aumenta la supervivencia de juveniles puede tener beneficios a corto plazo, pero en el largo plazo puede provocar disminuciones en la abundancia de las presas y posiblemente en la estructura de la vegetación del humedal.

KNOWLEDGE OF A species' population biology is crucial for understanding factors influencing its viability (Ricklefs 1973, Stearns 1992). Survival of individuals between the fledging and adult stages (hereafter "juvenile survival") has rarely been considered, because of difficulty in assessing factors that influence juvenile survival of birds (Miller et al. 1997, Ganey et al. 1998). Because of their lack of experience, juveniles may be more sensitive than adults to both external (e.g. habitat quality) and internal (e.g. behavioral and physiological) factors that influence survival (e.g. Cooch et al. 1991, Sedinger et al. 1995, Hakkarainen et al. 1997, Miller et al. 1997, Ganey et al. 1998).

Here, we consider factors that influence juvenile survival of the endangered Snail Kite (Rostrhamus sociabilis) in Florida. A wetlanddependent species, Snail Kites exhibit nomadic tendencies (Bennetts and Kitchens 1997a, b; 2000) that likely result from living in an unpredictable environment (Beissinger 1986). Philopatry to a breeding site or natal area is relatively low, as compared with most birds species (Bennetts and Kitchens 1997a), especially birds of prey. Movement activity is high, with $25 \%$ of adults and $20 \%$ of juveniles ( $<1$ year old) moving at least once within a given month to a different wetland unit (Bennetts and Kitchens 2000). Water level-in particular, low water level-has been suggested as one reason why Snail Kites move (Takekawa and Beissinger 1989, Sykes et al. 1995, Beissinger 1988). However, Bennetts and Kitchens (2000) found no direct relationship between water level and movement. Survival of adults is high and relatively constant over years and regions, with juvenile survival exhibiting variation among years and regions (Bennetts et al. 1999). Bennetts and Kitchens (1999) found that the highest risk of mortality for juvenile Snail Kites was the postfledging stage, the period from fledging to independence.

Habitat quality is frequently mentioned as a factor influencing juvenile survival (e.g. Hakkarainen et al. 1997, Miller et al. 1997, Ganey et al. 1988), and water level has been suggested as an important element of habitat quality for Snail Kites (Kitchens et al. 2001); Beissinger (1995) included it as a driving variable in a model of Snail Kite population viability. Beyond the possible influence on movement activity mentioned above, water level may influence survival of Snail Kites, with low water level or "drought" decreasing survival (Beissinger 1986, Takekawa and Beissinger 1989, Snyder et al. 1989). Although Bennetts et al. (1999) found variation in juvenile survival over time and space, they did not explicitly test water level as an environmental variable possibly driving those spatial and temporal effects.

Dispersal behavior is another factor that may affect juvenile survival. Dispersal of individuals from unfavorable sites is a demographic process that may affect population viability. From a demographic perspective, there has been considerable focus on survival and reproduction in bird populations. However, studies of dispersal (i.e. immigration and emigration) and its corresponding effect on population change have generally been lacking (North 1988, Clobert et al. 2001). Although site philopatry and local familiarity can enhance animals' ability to locate available food resources, avoid predators, and resist competitive intrusion (Alerstam and Enckell 1979, Pärt 1995), dispersal can be advantageous, and even necessary, as environments become less stable and predictable (Wiens 1976). Despite the potential advantage of dispersal in escaping local conditions, there may be substantial costs associated with dispersal into unfamiliar or inhospitable habitat (e.g. Fahrig and Paloheimo 1988, Opdam 1991). However, such costs have seldom been empirically demonstrated, and some recent studies (e.g. Gillis and Krebs 2000) have failed to find significant costs of dispersal.

Natal dispersal is defined as movement of an individual from its birth place to its place of reproduction (Greenwood 1980, Johnson and Gaines 1990). Here, we explicitly consider cost of natal dispersal as a potential effect on survival of juvenile Snail Kites. Studies of 
dispersal (Bennetts and Kitchens 1997a, b) suggest that the population of Snail Kites in Florida is a continuous population distributed among a network of heterogeneous wetland units in central and southern Florida. Dispersal of juveniles from the natal wetland unit within their first year was $81 \%$ (Bennetts and Kitchens 2000), and juveniles are known to reproduce in numerous wetland units-not just their natal one-during their lifetimes (Bennetts and Kitchens 1997a). To distinguish between the evolutionary definition of natal dispersal and the unique nomadic affinities of Snail Kites, we follow the clarification of Bennetts and Kitchens (2000) by defining "natal departure" as the initial dispersal of a juvenile from its natal wetland unit, regardless of the bird's future breeding status. Also, we assess whether spatial and temporal differences in juvenile survival could be explained by environmental conditions.

\section{Methods}

The present study encompassed the entire Snail Kite range in central and southern Florida (see Sykes et al. 1995 and Bennetts and Kitchens 1997a for more detail). We equipped juvenile Snail Kites with radiotransmitters (1992: Advanced Telemetry Systems [ATS], Isanti, Minnesota; 1993: ATS, Telonics, Mesa, Arizona, and Holohil Systems, Carp, Ontario; 1994: Holohil Systems) (hereafter "transmitters") prior to fledging, at approximately 30-35 days of age, from 1992 through 1994. Juveniles were captured by hand at the nest prior to fledging. To maintain independence in our sampling effort, we equipped only one juvenile per nest with a transmitter. Transmitters were attached to juveniles with backpack harnesses weighing $15 \mathrm{~g}$. Body mass of Snail Kites averaged $394 \mathrm{~g}$ for males and $446 \mathrm{~g}$ for females (Sykes et al. 1995); transmitters averaged $3.8 \%$ and $3.4 \%$ of the body mass of males and females, respectively. We chose numbers of juveniles from each wetland unit to be fitted with transmitters to approximate statewide distribution of the species. Transmitters contained mortality sensors that changed pulse rates if the transmitter did not move in a 6- to 8-h period. We located radiotagged birds once a month by aircraft or ground search to determine survival and location. Fates of individuals with a transmitter emitting a mortality signal were verified on the ground.

The postfledging dependency period of Snail Kites lasts $\sim 42$ days (Snyder et al. 1989), with adults continuing to feed young until they are 63-77 days old (Beissinger and Snyder 1987, Beissinger 1988). Percentage of juveniles dispersing from the natal wetland unit within their first 90 days is relatively high (60\%; Bennetts and Kitchens 2000). Bennetts and Kitchens (1999) showed that survival rate of juveniles was similar to adult survival 120 days after fledging $(\sim 150$ days old). In the present study, we considered the time period from fledging ( $\sim 30$ days old) to 120 days postfledging as the juvenile period. Because juveniles were located once a month, four locations were obtained on each individual.

Explanatory variables. - We considered effects of natal departure, year, month, region, age, and water levels on juvenile survival. Natal departure was treated as a two-level categorical variable; an individual was categorized as "departed" if it left its natal wetland unit at any time during its first 120 days postfledging. Bennetts et al. (1999) showed that annual juvenile survival, in contrast to that of adults, differed from year to year. We included the same yearly effects in our analysis. We also included month as a variable to test whether a more specific temporal scale better explained temporal variability in juvenile survival. "Month" was simply the month of the calendar year in which the juvenile was located, starting with the month the transmitter was placed on the individual. We also included the same regional effects (i.e. Everglades, Lake Okeechobee, Loxahatchee Slough, Kissimmee Chain-of-Lakes, Upper St. Johns River) found by Bennetts et al. (1999). We were unable to examine the influence of smaller spatial effects, such as specific wetland units (e.g. Water Conservation Areas 2A, 2B, 3A; Lake Kissimmee; Big Cypress National Preserve), because 9 of 15 wetland units used in the analysis had sample sizes $<20$ and thus do not support such an analysis. Exact ages of individuals were not known because of unknown hatch dates, asynchrony in hatching, and individual heterogeneity in growth rates. We simply categorized age starting with placement of the transmitter as day 30 , then followed a monthly interval of 30 days in locating individuals. Thus, age is categorized for an individual as 30,60 , 90 , and 120 days.

We focused on monthly minimum water level at each of 15 sites over the period of the study. Minimum water level (hereafter "water level") for a given year typically occurs about the time that young fledge from the nest, in May or June (Fig. 1). Because water depth can be highly spatially variable within a wetland unit and reliable ground-elevation data to estimate site-specific depth within a wetland unit are lacking, we used variation in mean elevation of monthly water surface in each wetland unit relative to mean sea level as our measure of water level (Bennetts and Kitchens 1997a, 2000; Dreitz et al. 2001). Specific gauges used for each wetland unit are reported in Bennetts and Kitchens (1997a). That procedure for quantifying water levels in Florida wetland units has been used in previous studies (Bennetts and Kitchens 1997a, 2000; Dreitz et al. 2001) and is comparable to qualitative assessments of water levels by Snyder et al. (1989) and Beissinger (1995). 


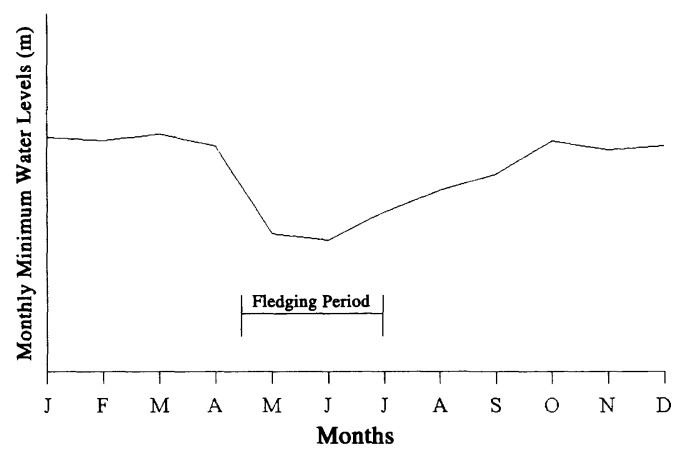

FIG. 1. Hydrograph illustrating monthly minimum water levels in Water Conservation Area 3A during 1994, in relation to fledgling period of Snail Kites.

Because water levels during the period of interest are considered non-drought levels - that is, relatively normal to high (Bennetts and Kitchens 1997a, 2000; Dreitz et al. 2001) - we did not include a categorical measure of water level in our analysis.

Model and model selection.-We used a generalized estimating equation (GEE) approach (Liang and Zeger 1986) to examine influence of natal dispersal and habitat quality on juvenile survival of Snail Kites. Generalized estimating equations are an extension of generalized linear models that account for the covariance structure of predictor variables. We had no a priori knowledge of how explanatory variables or interactions between them would influence juvenile survival. Consequently, we built all possible additive models in which the variables were not confounded with one another (e.g. month is confounded with year). In our data set, variables such as year, month, and region are correlated with water levels. Not accounting for correlations in the data will produce incorrect standard errors. For example, with positive correlations, standard errors are underestimated for between-level effects and overestimated for withinlevel effects, resulting in inefficient estimation (Stokes et al. 2000). The generalized estimating equation for juvenile survival $S(\beta)$ is

$$
S(\beta)=\sum_{i=1}^{N} \frac{\partial \mu^{\prime}}{\partial \beta} V_{i}^{-1}\left[Y_{i}-\mu_{i}(\beta)\right]
$$

where $\mu_{i}$ is the corresponding vector of means $\mu_{i}=$ $\left(\mu_{i 1}, \ldots, \mu_{i t}\right)^{\prime}, Y_{i}=\left(y_{i 1}, y_{i{ }^{\prime}}, \ldots, y_{i t 1}\right)$, and $V_{i}$ is an estimator of the working covariance matrix of $Y_{i}$. These equations are similar to the generalized linear model estimating equations, except that, because there are multiple outcomes, they include a vector of means instead of a single mean, and a covariance matrix instead of a scalar variance. The covariance matrix of $Y_{i}$ is specified as the estimator

$$
\mathrm{V}_{i}=\phi \mathrm{A}_{i}^{\frac{1}{2}} \mathrm{R}_{i}(\alpha) \mathrm{A}_{i}^{\frac{1}{2}}
$$

where $\mathrm{A}_{i}$ is a $t_{i} \times t_{i}$ diagonal matrix with $v\left(\mu_{\mathrm{ij}}\right)$ as the $j$ th diagonal element, and $R_{i}(\alpha)$ is the working correlation matrix. We used an identity link function and delineated our working correlation matrix to be compound-symmetric, meaning that our analysis was equivalent to random-effects models that take into account natural variation among parameters and treat them as arising from an underlying distribution rather than a fixed parameter (Horton and Lipsitz 1999). Random-effects models also include an additional parameter in the model that accounts for residual variation or variation not described in other parameters. That results in one more parameter in a random-effects model than in the comparable fixedeffects model. Table 1 demonstrates the data format we used. As with most analyses, this is dependent on the analytical modular and statistical package. We used PROC GENMOD in SAS (version 9, SAS Institute, Cary, North Carolina) to conduct the GEE.

Kullback-Leibler information (Kullback and Leibler 1951) was the basis for our model selection and inference. Akaike developed a way to estimate the relative Kullback-Liebler information, based on the maximized value of a likelihood function termed Akaike's Information Criterion (AIC) (Akaike 1973, Shibata 1989, Burnham and Anderson 2002). Modifications to AIC have been developed for nonlikelihood-based methods, such as GEEs (Pan 2001a, b). The quasi-likelihood criterion (QIC) model-selection approach replaces the likelihood in AIC with the quasi-likelihood, and a proper adjustment is made for the penalty term (Pan 2001a). The equation for $\mathrm{QIC}$ is

$$
\mathrm{QIC}=-2 \mathrm{Q}(\hat{\boldsymbol{\beta}} ; \mathrm{I})+2 \operatorname{trace}\left(\hat{\Omega}_{I} \hat{V}_{r}\right)
$$

where $V_{\hat{r}}$ is the $\operatorname{cov}(\hat{\beta})$ that is consistently estimated by the robust or sandwich estimator (Liang and Zeger 1986) and $\Omega_{I}$ is consistently estimated by its empirical estimator

$$
\hat{\Omega}_{l}=-\partial Q(\beta ; \mathrm{I}) /\left.\partial \beta \partial \beta^{\prime}\right|_{\beta=\hat{\beta}}
$$

Note that $\hat{V}_{r}$ and $\hat{\Omega}_{I}$ are directly available from the model-fitting results in statistical packages such as SAS and S-PLUS. QIC model selection is still an estimate of the relative Kullback-Leibler information that balances the trade-offs between bias and precision of an estimator (Pan 2001b) and has numerous advantages over traditional methods of model selection used in regression analysis (McQuarrie and Tsai 1998). We used two measures to provide further insight into the amount of uncertainty in model selection. The first measure is the difference in QIC between the best approximating model and all other models (Lebreton et al. 1992, Burnham and Anderson 2002), termed $\triangle \mathrm{QIC}$. The second measure calibrates models to provide relative plausibility by normalizing each model on the basis of its $\triangle$ QIC value, termed "model weight" (Anderson and Burnham 1999, Burnham and Anderson 2002). Model weight is calculated as 
TABLE 1. Example data to show the format we used to conduct a generalized estimating equation to understand effects of natal dispersal and water levels on juvenile survival on Snail Kites. Data were analyzed using PROC GENMOD in SAS (version 9).

\begin{tabular}{lccccccc}
\hline \hline Year & $\begin{array}{c}\text { Bird } \\
\text { frequency }\end{array}$ & Survived & Dispersed & Month & $\begin{array}{c}\text { Age } \\
\text { (days) }\end{array}$ & $\begin{array}{c}\text { Region } \\
\text { (a) }\end{array}$ & $\begin{array}{c}\text { Water } \\
\text { levels }\end{array}$ \\
\hline 1992 & 152.032 & Yes & No & April & 30 & Okee & 0.7619 \\
1992 & 152.032 & Yes & No & May & 60 & Okee & 0.8415 \\
1992 & 152.032 & Yes & No & June & 90 & Okee & 0.7303 \\
1992 & 152.032 & Yes & No & July & 120 & Okee & 1.220 \\
1993 & 153.750 & Yes & No & June & 30 & Kiss & 0.2768 \\
1993 & 153.750 & Yes & No & July & 60 & Kiss & -0.0833 \\
1993 & 153.750 & Yes & Yes & August & 90 & Okee & -0.2484 \\
1993 & 153.750 & Yes & Yes & September & 120 & Kiss & -0.5294 \\
1992 & 152.73 & Yes & No & May & 30 & Ever & -0.9388 \\
1992 & 152.73 & No & No & June & 60 & Ever & -0.8447 \\
1994 & 152.229 & Yes & No & June & 30 & Ever & 0.9149 \\
1994 & 152.229 & Yes & Yes & July & 60 & Ever & 0.2143 \\
1994 & 152.229 & No & Yes & August & 90 & Ever & 0.29630 \\
1992 & 152.263 & Yes & No & May & 30 & Kiss & 0.4970 \\
1992 & 152.263 & Yes & Yes & June & 60 & Kiss & 0.17860 \\
1992 & 152.263 & Yes & Yes & July & 90 & Kiss & 0.2349 \\
1992 & 152.263 & Yes & Yes & August & 120 & Ever & 0.3456 \\
\hline
\end{tabular}

${ }^{\circledR}$ Regions: Ever $=$ Everglades, Okee = Lake Okeechobee, and Kiss = Kissimee Chain-of-Lakes (see Bennetts et al. 1999 for more detail).

$$
w_{i}=\frac{\exp \left(\frac{-\Delta_{i}}{2}\right)}{\sum_{j}\left\{\exp \left(\frac{-\Delta_{j}}{2}\right)\right\}}
$$

where $i$ is a given model.

Following the criteria for likelihood-based approaches (Anderson and Burnham 1999), all additive models with $\triangle \mathrm{QIC} \leq 2$ were considered as good candidate models for explaining patterns in the data. We followed our additive model analysis by an exploratory analysis, wherein we constructed new models containing all possible interactions between effects in a good suite of candidate models. We used the same modelselection criteria as stated above to determine the best approximating model for the second analysis.

\section{Results}

A total of 117 transmitters were placed on juvenile Snail Kites from 1992 to 1994: 37 individuals in 1992, 40 in 1993, and 40 in 1994. For $31 \%$ of those juveniles, survival and natal dispersal status could not be determined for the entire 120-day postfledging period in each year because of radio loss. We treated the survival and dispersal status in those cases as missing values for an individual. Of the juveniles that departed ( $n=39), 77 \%$ did so by 60 days postfledging and $80 \%$ survived to 120 days postfledging.
Natal departure was lowest in 1992 (14\%) and relatively higher in 1993 (40\%) and 1994 (45\%). Wetland units in the Everglades region had the most (60\%) juveniles that departed, with 95\% of those juveniles departing to another wetland unit within the Everglades region. Similarly, of the 39 juveniles that departed, 35\% departed to a wetland unit not in their natal region. When they moved ( $n=31)$ to other wetland units, they chose places where water level was higher (Fig. 2).

Three of the additive-effects models had a $\triangle Q I C \leq 2$ (Table 2). Model weights for the top model (Year+Age+Water) suggested that it was twice as likely as the next-best model (Year+Water). Using the top three models, we developed the additional models listed in Table 3. The results indicate that including an interaction term or terms in each of the additive models did not increase the model's ability to approximate the data. Five models had a $\Delta \mathrm{QIC} \leq 2$, and each of those models contained the effects of year and water levels on juvenile survival (Table 3). Our top model suggested that juvenile survival differed between years and by age, and was influenced by water levels. Coefficients for the effects in that model (Year+Age+Water; Table 3) showed that year had a negative effect on juvenile survival $(-0.037 \pm 0.017 \mathrm{SE})$. Although the effect of age was negative, magnitude of the estimated coefficient was small $(-0.001 \pm 0.001 \mathrm{SE})$. Water 


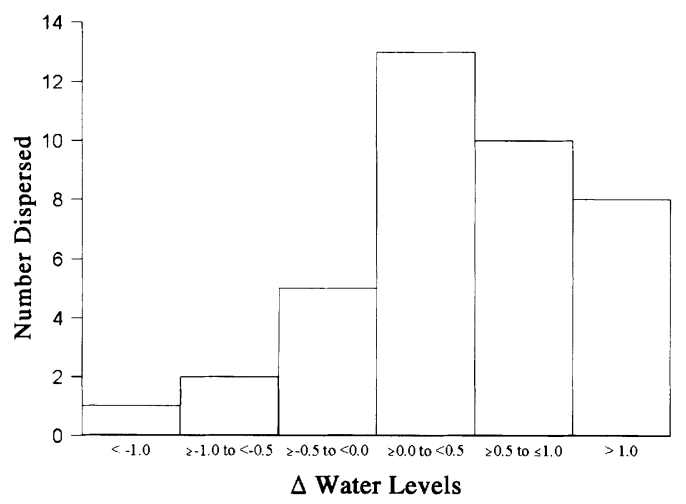

FIG. 2. Distribution of changes in water levels from a juvenile Snail Kite's natal wetland unit to the wetland unit to which it dispersed.

levels had a positive effect $(0.0523 \pm 0.0252 \mathrm{SE})$. Natal departure was another effect contained in our top models with $\Delta \mathrm{QIC} \leq 2$; however, that effect only influenced juvenile survival with the inclusion of year, age, and water-level effects. Using model averaging (Burnham and Anderson 2002), our estimate of survival from fledging to 120 days postfledging for all years was $0.713 \pm 0.044 \mathrm{SE}$; yearly estimates were $0.727 \pm$ $0.041 \mathrm{SE}, 0.719 \pm 0.042 \mathrm{SE}$, and $0.712 \pm 0.042 \mathrm{SE}$ for 1992, 1993, and 1994, respectively.

\section{Discussion}

Our juvenile-survival estimate of $71.3 \%$ at 120 days postfledging is similar to results of another study (Bennetts and Kitchens 2000). Our results are also consistent with previous studies indicating that year (Bennetts et al. 1999), age (Bennetts and Kitchens 1999), and water level (Beissinger 1986, Beissinger and Snyder 1987, Beissinger 1995) influence juvenile survival in Snail Kites. The most parsimonious model selected by the information criterion included separate estimates for each year of the study, age of the juvenile, and water levels. However, on the basis of $\triangle \mathrm{QIC}$ values and model weights, the selected best-approximating model is not convincingly best, which suggests that modelselection uncertainty is relatively high for our models (Burnham and Anderson 2002). However, we believe that both year and water level explain some of the variation in juvenile survival, considering that those effects were in each of our best-approximating models.

Influence of year on juvenile survival, also noted by Bennetts and Kitchens (1999) and Bennetts et al. (1999), was further supported by the present study. In our top model, the coefficient for year was relatively small and precise $(-0.037 \pm 0.017 \mathrm{SE})$, resulting in a relatively small

TABLE 2. Generalized estimating equation models where $\triangle \mathrm{QIC}<7 . \Delta \mathrm{QIC}$ indicates the difference between a model and the model with the lowest QIC value, and the model weight is the normalized value of the model based on its $\triangle \mathrm{QIC}$ value.

\begin{tabular}{lcccc}
\hline Model & $\begin{array}{c}\text { Number of } \\
\text { parameters }\end{array}$ & QIC & $\Delta$ QIC & $\begin{array}{c}\text { Model } \\
\text { weight }\end{array}$ \\
\hline Year+age+water & 5 & -34.7989 & 0.0000 & 0.3014 \\
Year+water & 4 & -33.0518 & 1.7472 & 0.1258 \\
Natal dispersal+year+age+water & 6 & -32.7920 & 2.0069 & 0.1105 \\
Natal dispersal+year+water & 5 & -31.5369 & 3.2620 & 0.0590 \\
Year+age & 4 & -31.5142 & 3.2848 & 0.0583 \\
Age+water & 4 & -31.2498 & 3.5492 & 0.0511 \\
Age & 3 & -30.3802 & 4.4187 & 0.0331 \\
Year+ age+region+water & 8 & -29.8472 & 4.9517 & 0.0253 \\
Natal dispersal+year+age & 5 & -29.5433 & 5.2556 & 0.0218 \\
Water & 3 & -29.4890 & 5.3099 & 0.0212 \\
Year & 3 & -29.4564 & 5.3425 & 0.0208 \\
Natal dispersal+age+water & 5 & -29.3059 & 5.4930 & 0.0193 \\
Natal dispersal+age & 4 & -28.5410 & 6.2580 & 0.0132 \\
Natal dispersal+water & 4 & -28.5308 & 6.2682 & 0.0131 \\
Natal dispersal+year & 4 & -28.4706 & 6.3284 & 0.0127 \\
No effect & 2 & -28.3812 & 6.4177 & 0.0122 \\
Year+region+water & 7 & -28.1525 & 6.6464 & 0.0109 \\
Age+region+water & 7 & -28.0753 & 6.7236 & 0.0105 \\
Natal dispersal+year+age+region+water & 9 & -27.8834 & 6.9155 & 0.0095 \\
\hline
\end{tabular}


TABLE 3. Generalized estimating equation models containing interaction terms derived from the top three additive models in Table 2. Models are listed in ascending order by QIC value and $\triangle \mathrm{QIC}$.

\begin{tabular}{|c|c|c|c|c|}
\hline Model & $\begin{array}{l}\text { Number of } \\
\text { parameters }\end{array}$ & QIC & $\Delta \mathrm{QIC}$ & $\begin{array}{l}\text { Model } \\
\text { weight }\end{array}$ \\
\hline Year+age+water & 5 & -34.7989 & 0.0000 & 0.2587 \\
\hline Year $\times$ age+water & 6 & -34.1964 & 1.6025 & 0.1161 \\
\hline Year+water & 4 & -33.0518 & 1.7472 & 0.1080 \\
\hline Year+age $\times$ water & 6 & -32.9960 & 1.8029 & 0.1050 \\
\hline Natal dispersal+year+age+water & 6 & -32.7920 & 2.0069 & 0.0948 \\
\hline Natal dispersal×year+age+water & 7 & -32.1491 & 2.6498 & 0.0688 \\
\hline Natal dispersal×age+year+water & 7 & -31.3507 & 3.4482 & 0.0461 \\
\hline Natal dispersal+year×age+water & 7 & -31.1799 & 3.6190 & 0.0424 \\
\hline Year×water & 5 & -31.1565 & 3.6424 & 0.0419 \\
\hline Natal dispersal+year+age×water & 7 & -31.0013 & 3.7976 & 0.0387 \\
\hline Natal dispersal×water+year+age & 7 & -30.7739 & 4.0250 & 0.0346 \\
\hline Natal dispersal×year+age×water & 8 & -30.2983 & 4.5007 & 0.0273 \\
\hline Natal dispersal $\times$ year $\times$ age + water & 10 & -38.1174 & 6.6815 & 0.0092 \\
\hline Year×age $\times$ water & 9 & -27.3344 & 7.4645 & 0.0062 \\
\hline Natal dispersal+year×age×water & 10 & -25.3114 & 9.4875 & 0.0023 \\
\hline Natal dispersal $\times$ year $\times$ age $\times$ water & 17 & -19.1654 & 15.6336 & 0.0001 \\
\hline
\end{tabular}

variation in yearly estimates of juvenile survival. Although the differences in our yearly estimates may have little biological significance, our analysis demonstrated that there is yearly variation in juvenile survival, which has been observed in numerous avian species. The reason for that yearly variation is unknown. Bennetts et al. (1999) suggested that yearly variation in annual estimates of juvenile survival is likely the result of lack of experience. Local habit quality for Snail Kites is quite variable within a given year in central and southern Florida (Beissinger 1986, Bennetts and Kitchens 1997a). Although adult kites are well adapted to variability in habitat quality, juveniles lack the knowledge of foraging strategies needed to locate alternative habitats when local habitat-quality becomes unfavorable, as when food resources are depleted (Bennetts and Kitchens 1999, Bennetts et al. 1999). Yearly variation in survival could also be a consequence of variation in daily water levels or water levels in preceding years, changes in vegetational structure, or some other component that varies yearly and that we did not measure here. It has been noted that other Snail Kite reproductive components, such as nest success and nest productivity, also exhibit yearly variation (Dreitz et al. 2001) and arguably also exhibit variation with water level (Beissinger 1995, Beissinger and Snyder 2002).

The present study shows that monthly water levels are positively correlated with survival of juvenile Snail Kites. Water levels in central and southern Florida rise concurrently with fledging of juveniles (Fig. 1), but rising water level does not necessarily cause higher survival of juveniles. As with many raptor species, survival rate for juveniles is lowest during postfledging -60 to 90 days old in Snail Kites (Bennetts and Kitchens 1999), coinciding with the year's lowest water levels. Here, $82 \%$ of juveniles that reached an age of 30-60 days after fledging did so from May to July - the end of the dry season and onset of the wet season in central and southern Florida (Fig. 1). During that period, monthly water levels are increasing as juveniles become independent and their survival rate increases. Thus, the positive coefficient for water levels may involve birds having survived that period of vulnerability. Bennetts et al. (2002) showed that annual juvenile survival was relatively high during a "high water event"; however, annual variability in juvenile survival could not be explained by the high water event alone.

For management purposes, we believe it may be problematic to infer that increasing water levels during fledging will increase juvenile survival. We feel that other concerns need to be addressed, including the life cycle of the almost exclusive food source of Snail Kites, the aquatic apple snail (Pomacea paludosa), an annual cycle with laying of egg clusters peaking in April, eggs hatching at the end of the dry season-beginning of the wet season (May-June) concurrent with a die-off of 
postreproductive adults, and young of the year (>25 mm) reaching adult size in 2 to 4 months (Fig. 3; Darby et al. 1997, 2003). Submerged egg clusters result in delayed development and decreased survival of embryos (Turner 1996). To increase water levels during the Snail Kite's fledging period (mid-April through June) would likely result in increasing mortality of viable egg clusters. Other concerns involve inundation of emergent vegetation. Apple snails have both lungs and gills and need emergent vegetation to surface when dissolved oxygen levels become depleted (McClary 1964).

Higher juvenile survival associated with higher water levels is certainly a positive shortterm effect. However, habitat degradation, such as depleted food abundance and reduced vegetative structure, associated with high or prolonged water levels, may offset those short-term benefits. We believe that long-term effects on Snail Kite habitat should not be overlooked. The central and southern Florida ecosystem is highly dynamic, experiencing continual spatial fluctuations in water levels. Those fluctuations are necessary for sustaining the habit quality of the wetland communities for Snail Kites (Kitchens et al. 2001). Maintaining consistently high water levels would likely be counterproductive for long-term management of Snail Kites.

Generalized estimating equations were developed to extend the generalized linear model to accommodate correlated data (Liang and Zeger 1986). The GEE methodology provides consistent estimators of regression coefficients and their variances under weak assumptions about the correlations among independent observations (Stokes et al. 2000). A fit statistic (i.e. goodness-of-fit test) is not available, but there is active research in that area (Barnhart and Williamson 1998, Pan 2002). Generalized estimating equations have been used in numerous fields (Horton and Lipsitz 1999), especially medicine (Therneau and Grambsch 2000), but seldom in ecology. We used GEEs to account for correlations within and between the repeated measurements in our study and to get reliable estimates of our regression coefficients.

In conclusion, the present study concentrated on one component of habitat quality-water levels - as a variable influencing juvenile Snail Kite survival. We believe that inclusion of (1) the dynamics of the kite's primary food source,

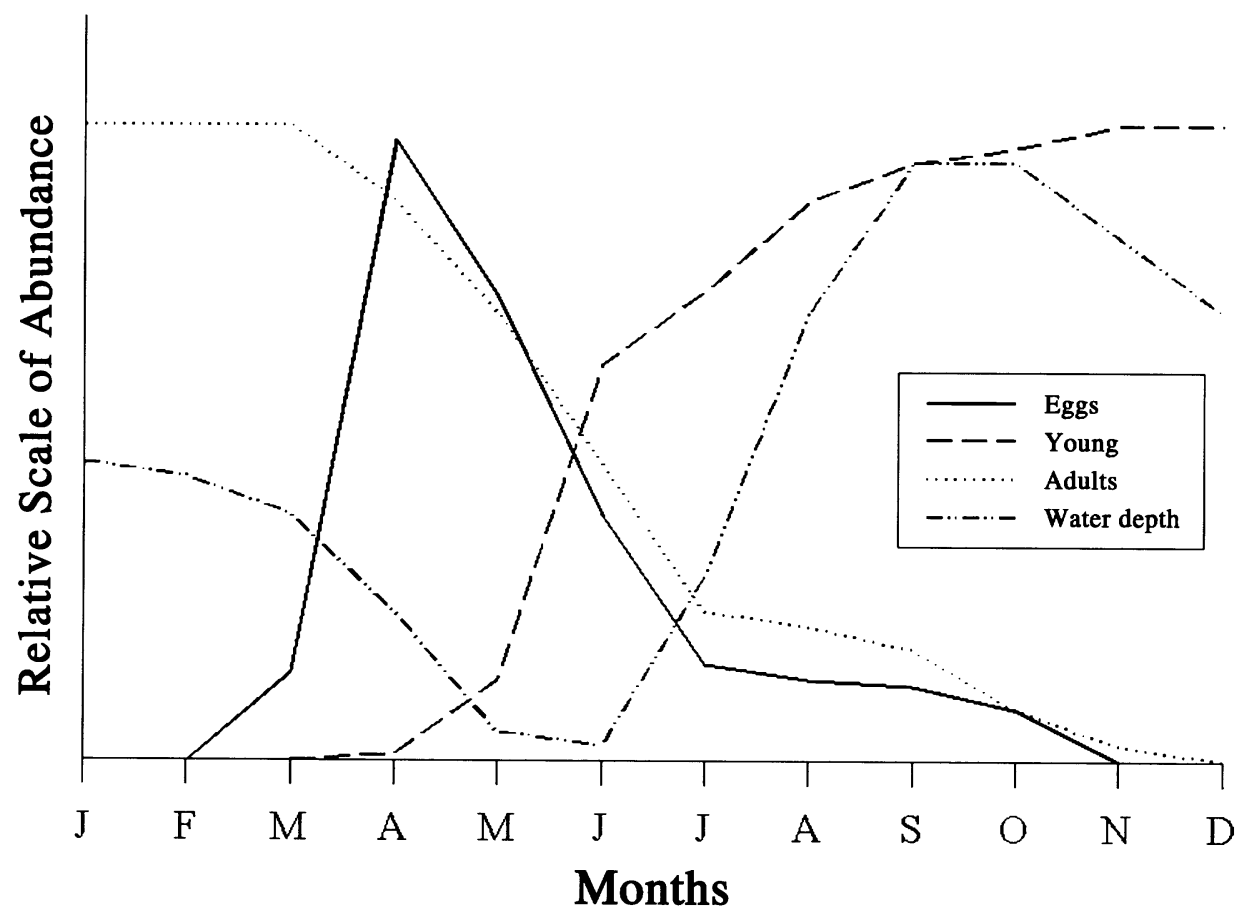

FIG. 3. Relative abundance of egg clusters ("Eggs"), young of the year snail (>25 mm; "Young"), and adult snails ("Adults") as related to water depth (adapted from Darby et al. 1997). 
the aquatic apple snail, and (2) vegetative struc $\rightarrow$ ture would provide additional insight toward understanding the influences of water levels on juvenile survival.

\section{ACKNOWLeDgments}

Financial support was provided by the National Park Service's Critical Ecosystems Studies Initiative, U.S. Fish and Wildlife Service, U.S. Army Corps of Engineers, U.S. Geological Survey-Biological Resources Division, South Florida Water Management District, and St. Johns Water Management District. We are grateful to L. Bjork, D. Boyd, P. Darby, K. Golden, H. Maier, S. McGehee, S. Severs, and P Valentine-Darby for field assistance. We thank J. Martin, W. Mooji, S. K. Skagen, and T. Stanley for helpful comments on the manuscript. This paper is contribution no. R-09834 of the Florida Agricultural Experiment Station Journal Series, Institute of Food and Agricultural Sciences, University of Florida.

\section{Literature Cited}

AкAIKe, H. 1973. Information theory and an extension of the maximum likelihood principle. Pages 267-181 in Proceedings of the 2nd International Symposium on Information Theory (B. Petrov and F. Csaki, Eds.). Akademiai Kiado, Budapest, Hungary.

Alerstam, T., AND P. H. ENCKell. 1979. Unpredictable habitats and evolution of bird migration. Oikos 33:228-232.

Anderson, D. R., And K. P. Burnham. 1999. General strategies for the analysis of ringing data. Bird Study 46 (Supplement):261-270.

Barnhart, H., and J. Williamson. 1998. Goodnessof-fit tests for GEE modeling with binary responses. Biometrics 54:720-729.

Beissinger, S. R. 1986. Demography, environmental uncertainty, and the evolution of mate desertion in the Snail Kite. Ecology 67:1445-1459.

Beissinger, S. R. 1988. Snail Kite. Pages 148-165 in Handbook of North American Birds, vol. 4 (R. S. Palmer, Ed.). Yale University Press, New Haven, Connecticut.

Beissinger, S. R. 1995. Modeling extinction in periodic environments: Everglades water levels and Snail Kite population viability. Ecological Applications 5:618-631.

Beissinger, S. R., And N. F. R. Snyder. 1987. Mate desertion in the Snail Kite. Animal Behaviour 35:477-487.

Beissinger, S. R., ANd N. F. R. SNyder. 2002. Water levels affect nest success of the Snail Kite in Florida: AIC and the omission of relevant can didate models. Condor 104:208-215.
Bennetts, R. E., V. J. Dreitz, W. M. Kitchens, J. E. Hines, and J. D. Nichols. 1999. Annual survival of Snail Kites in Florida with comparisons between radiotelemetry and capture-recapture data. Auk 116:435-447.

Bennetts, R. E., and W. M. Kitchens. 1997a. The demography and movements of Snail Kites in Florida. U.S. Geological Survey, Biological Resources Division, Florida Cooperative Fish and Wildlife Research Unit, Technical Report no. 56, Gainesville.

BennetTs, R. E., AND W. M. Kitchens. $1997 \mathrm{~b}$. Population dynamics and conservation of Snail Kites in Florida: The importance of spatial and temporal scale. Colonial Waterbirds 20:324-329.

Bennetts, R. E., and W. M. Kitchens. 1999. Withinsurvival patterns of Snail Kites in Florida. Journal of Field Ornithology 70:268-275.

Bennetts, R. E., and W. M. Kitchens. 2000. Factors influencing movement probabilities of a nomadic food specialist: Proximate foraging benefits or ultimate gains from exploration? Oikos 91:459-467.

$\rightarrow$ Bennetts, R. E., W. M. Kitchens, and V. J. Dreitz. 2002. Influence of an extreme high water event on survival, reproduction, and distribution of Snail Kites in Florida, USA. Wetlands 22:366-373.

Burnham, K. P., And D. R. Anderson. 2002. Model Selection and Inference, 2nd ed. SpringerVerlag, New York.

Clobert, J., J. D. Nichols, E. Danchin, and A. A. Dhondt. 2001. Dispersal. Oxford University Press, Oxford.

Cooch, E. G., D. B. Lank, A. Dzubin, R. F. Rockwell, AND F. Cooke. 1991. Body size variation in Lesser Snow Geese: Seasonal variation in gosling growth rate. Ecology 72:503-512.

Darby, P. C., P. L. Valentine-Darby, R. E. Bennetts, J. D. Croop, H. F. Percival, and W. M. Kitchens. 1997. Ecological studies of apple snails (Pomacea paludosa Say). U.S. Geological Survey, Biological Resources Division, Florida Cooperative Fish and Wildlife Research Unit. Special Publication SJ98-SP6, Gainesville.

Darby, P. C., P. L. Valentine-Darby, and H. F. Percival. 2003. Dry season survival in a Florida apple snail (Pomacea paludosa Say) population. Malacologia 45:179-184.

Dreitz, V. J., R. E. Bennetts, B. Toland, W. M. Kitchens, and M. W. Collopy. 2001. Spatial and temporal variability in nest success of Snail Kite in Florida: A meta-analysis. Condor 103:502-509.

Fahrig, L., And J. Paloheimo. 1988. Effect of spatial arrangement of habitat patches on local population size. Ecology 69:468-475.

Ganey, J. L., W. M. Block, J. K. Dwyer, B. E. Strohmeyer, and J. S. Jenness. 1998. Dispersal 
movements and survival rates of juvenile Mexican Spotted Owls in northern Arizona. Wilson Bulletin 110:206-217.

Gillis, E. A., ANd C. J. Krebs. 2000. Survival of dispersing versus philopatric juvenile snowshoe hares: Do dispersers die? Oikos 90:343-346.

Greenwood, P. J. 1980. Mating systems, philopatry and dispersal in birds and mammals. Animal Behaviour 28:1140-1162.

Hakkarainen, H., V. Koivunen, and E. KorpimäKi. 1997. Reproductive success and parental effort of Tengmalm's Owls: Effects of spatial and temporal variation in habitat quality. Ecoscience 4:35-42.

Horton, N. J., and S. R. Lipsitz. 1999. Review of software to fit generalized estimating equation regression models. American Statistician 53 160-169.

Johnson, M. L., AND M. S. Gaines. 1990. Evolution of dispersal: Theoretical models and empirical tests using birds and mammals. Annual Review of Ecology and Systematics 21:449-480.

Kitchens, W. M., R. E. Bennetts, And D. L. DeAngelis. 2001. Linkages between the Snail Kite population and wetland dynamics in a highly fragmented South Florida hydroscape. Pages 183-204 in The Everglades, Florida Bay, and Coral Reefs of the Florida Keys: An Ecosystem Sourcebook (J. W. Porter and K. G. Porter, Eds.). CRC Press, Delray Beach, Florida.

Kullback, S., and R. A. Leibler. 1951. On information and sufficiency. Annals of Mathematical Statistics 22:79-86.

Lebreton, J.-D., K. P. Burnham, J. Clobert, and D. R. Anderson. 1992. Modeling survival and testing biological hypotheses using marked animals: A unified approach with case studies. Ecological Monographs 62:67-118.

LianG, K. Y., AND S. L. Zeger. 1986. Longitudinal data analysis using generalized linear models. Biometrika 73:13-22.

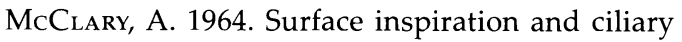
feeding in Pomacea paludosa (Prosobranchia: Mesogastropoda: Ampullariidae). Malacologia 2:87-101.

McQuarrie, A. D. R., And C. L. Tsai. 1998. Regression and Time Series Model Selection. World Scientific Publishers, Singapore.

Miller, G. S., R. J. Small, and E. C. Meslow. 1997. Habitat selection by Spotted Owls during natal dispersal in western Oregon. Journal of Wildlife Management 61:140-150.

North, P. M. 1988. A brief review of the (lack of) statistics of bird dispersal. Acta Ornithologica 24:63-74.

$\rightarrow$ Opdam, P. 1991. Metapopulation theory and habitat fragmentation: A review of Holarctic breeding bird studies. Landscape Ecology 5:93-106.
PAN, W. 2001a. Akaike's Information Criterion in generalized estimating equations. Biometrics 57:120-125.

PAN, W. 2001b. Model selection in estimating equations. Biometrics 57:529-534.

PAN, W. 2002. Goodness-of fit tests for GEE with correlated binary data. Scandinavian Journal of Statistics 29:101-110.

PäRT, T. 1995. The importance of local familiarity and search costs for age- and sex-biased philoparty in the Collared Flycatcher. Animal Behaviour 49:1029-1038.

Ricklefs, R. E. 1973. Fecundity, mortality, and avian demography. Pages 366-435 in Breeding Biology of Birds (D. S. Farner, Ed.). National Academy of Sciences, Washington, D.C.

Sedinger, J. S., P. L. Flint, and M. S. Lindberg. 1995. Environmental influence on life-history traits: Growth, survival, and fecundity in Black Brant (Branta bernicla). Ecology 76:2402-2414.

Shibata, R. 1989. Statistical aspects of model selection. Pages 215-240 in From Data to Model (J. C. Williams, Ed.). Springer-Verlag, New York.

SNYder, N. F. R., S. R. BEISSINGER, AND R. Chandler. 1989. Reproduction and demography of the Florida Everglade (Snail) Kite. Condor 91: 300-316.

Stearns, S. C. 1992. The Evolution of Life Histories. Oxford University Press, Oxford.

Stokes, M. E., C. S. Davies, and G. G. Косн. 2000. Categorical Data Analysis Using the SAS System, 2nd ed. SAS Institute, Cary, North Carolina.

Sykes, P. W., Jr., R. A. Rodgers, JR., ANd R. E. Bennetts. 1995. Snail Kite (Rostrhamus sociabilis). In The Birds of North America, no. 171 (A. Poole and F. Gill, Eds.). Academy of Natural Sciences, Philadelphia, and American Ornithologists' Union, Washington D.C.

Takekawa, J. E., And S. R. Beissinger. 1989. Cyclic drought, dispersal, and conservation of the Snail Kite in Florida: Lessons in critical habitat. Conservation Biology 3:302-311

Therneau, T. M., and P. M. Grambsch. 2000. Modeling Survival Data: Extending the Cox Model. Springer-Verlag, New York.

TURner, R. L. 1996. Use of stems of emergent vegetation for oviposition by the Florida apple snail (Pomacea paludosa), and implications for marsh management. Florida Scientist 59:34-49.

Wiens, J. A. 1976. Population responses to patchy environments. Annual Review of Ecology and Systematics 7:81-120.

Associate Editor: K. G. Smith 